\title{
CONSIDERATIONS ON THE AGE OF THE "GLIMEE" IN TRANSYLVANIA
}

\author{
Sorina FĂRCAŞ ${ }^{1}$, Tudor Mihai URSU ${ }^{1 *}$, Vasile Viorel POP ${ }^{2}$, Ioan TANŢÄU ${ }^{3}$, Anamaria ROMAN ${ }^{1}$ \\ ${ }^{1}$ National Institute of Research and Development for Biological Sciences, Institute of Biological Research Cluj, \\ 48 Republicii str., RO-400015 Cluj-Napoca, Romania \\ ${ }^{2}$ National College George Coşbuc, 70-72 Avram Iancu str., RO-400000, Cluj-Napoca, Romania \\ ${ }^{3}$ Babeş-Bolyai University, Faculty of Biology and Geology, 1 Kogălniceanu str., \\ RO-400084, Cluj-Napoca, Romania \\ e-mail: tudor.ursu@icbcluj.ro
}

\begin{abstract}
The paper is a synthesis of the palynological studies that have addressed the age of landslides in Transylvania. We discuss the configuration of the paleo-vegetation in the respective areas, but also the probable factors, abiotic or biotic, which promoted the landslides and the relative period when they occurred in Transylvania. The analysis indicates two major periods of onset for landslides, the Pleistocene and Holocene.
\end{abstract}

Key words: Landslides, Palynological Analyses, Pleistocene, Holocene, Paleoclimate.

\section{Introduction}

Glimee type landslides (massive, deep landslides on slopes) are specific to the Transylvanian Plain, Târnavelor Plateau, Someşan Plateau, Moldavian Plateau, Getic Plateau and in some regions of the Subcarpathians.

It is generally accepted that the development of the glimee was favoured by the climatic conditions of the Late Pleistocene - Early Holocene, respectively the Preboreal and Boreal ages. However, even under current climatic conditions, the periods with exceptional rainfall have shown that the landslides continue to evolve, with numerous reactivations.

The most important factors that trigger glimee are variations in the volume and humidity of rock masses, torrential rainfall, earthquakes, human impact - such as cutting down trees on slopes, etc. Most of them occur after prolonged wet periods (spring, autumn), torrential summer rains or after a long period of drought on highly fragmented terrain [14].

The aim of this work is to estimate the relative period when most of the glimee occurred in Transylvania, and to discuss their probable trigger factors and the significance of these insights in the wider context of climate change.

Among the published works that have presented palynological analysis results from the Transylvanian area we have selected those which, through their geographical location and the age of their peat deposits, provide evidence regarding landslides in Transylvania. These data were checked against other works regarding the age of landslides in the study area and some recent works discussing the glimee in the Moldavian Plateau. 


\section{Results and Discussions}

The analyzed palynological sites are presented in Table 1, while their geographical distribution as well as the location of the most important glimee in the Transylvanian Depression are shown in Figure 1.

The glimee are very typical for the landscape of the Transylvanian Depression and play an important role in the evolution of the Transylvanian landscape by resizing the slopes [32]. Due to the extensive areas that they have affected, they are considered "catastrophic moments in the evolution of the slopes" [15]. The glimee evolution is influenced by slope, aspect, lithology and land use [20]. A slope affected by landslides continues to evolve by forming new landslide bodies that overlap the old ones [32].

Several studies have addressed the relative age of landslides [12, 23, 24, 35]. Surdeanu et al. [33] consider that the $\mathrm{C} 14$ dating and also the recording of large-scale movements on the slopes of the Transylvanian Plain support a new interpretation of the age established by spore-pollen analyses. If the genesis of some glimee is related to mass movement processes, others are generated by erosive processes. Surdeanu et al. [33] consider, regarding the lithological structure, that "the presence of sands is what gives a certain direction to the evolution". Roșian [29], shares the opinion of Jakab [15] that it is not possible to state a general age for all glimee, these being triggered, both in the Pleistocene and in the Holocene, by certain favourable conditions, specific to particular moments and not periods.

Nevertheless, given the scarcity of $\mathrm{C} 14$ datings, palynological analyses remain a useful resource that needs to be considered in determining the age of landslides, including the glimee.

G. Pop [28] attributes a Subatlantic age to certain landslides in Transylvania, based on the pollen diagram from Sălicea [26], although E. Pop supported the Atlantic age of the swamp. The author concludes that the general process of landslides in Transylvania is connected to the main wet period of the Postglacial, the Subatlantic.

However, Lupșa [18] resumes and completes the palynological analysis of the mesotrophic swamp at Sălicea, published by Pop in 1932; the diagram reflects the most representative hornbeam phase from the SE Carpathian area, attesting to the relatively old, Atlantic age of the swamp. In a previous work [23] Morariu indicates a glacial age for many of the landslide's areas from Transylvania.

Also, as Morariu et al. [24] observe, the age of landslides is related to the processes that trigger them. They note a correlation between the area of landslides and the area occupied by Sarmatian formations, where intercalations of sands, sandstones and conglomerates are common, between layers of marl and limestone, producing the necessary conditions for large-scale landslides. Also, according to the authors, the monoclinal or slightly wrinkled structure also promotes the formation of landslides. The authors discuss the situation of landslides at Bozieș, Şaeș, Dracășviz, Movile and Sălicea, but also refer to other sites from Transylvania, and quote related studies that support the age of landslides. The five areas included in the palynological research indicate different ages for the sedimentation process: Late Glacial-Preboreal at Dracășviz and Boreal-Atlantic at Şaeș, Bozieș, Sălicea, and Movile. Based on the pollen diagrams, the authors conclude the existence of several "phases" of landslides: an older phase in the PleistocenePreboreal, reflected in the pollen diagram from Dracaşviz, and another in the Boreal, but without excluding the possibility of new phases in the wet periods of the Postglacial, particularly in the Subatlantic. 
Partially replicating these studies, Tanţău and Fărcaș [35] perform palynological analyses at Dracășviz, more detailed than their predecessors, revealing, albeit lacunar, the vegetation history in the Dracășviz region starting with the end of the Late Glacial / Preboreal until the Subatlantic, with the 5 phases of vegetation described by E. Pop [26] for the lower altitude areas from the territory of Romania: the pine phase (Pinus), the pine-spruce transition phase (Pinus-Picea), the phase of mixed oaks, with spruce and hazel (Quercetum mixtum-Picea-Corylus), the hornbeam phase (Carpinus) and the beech phase (Fagus). There is an evident continuity of mixed oak forests in the area, from the Boreal to the historical period, up to the present day. According to the authors, "the hypothesis of Pleistocene landslides in this geographical region was confirmed, given the preBoreal age of the peat bog, formed in a pre-existing depression that had developed due to the landslide".

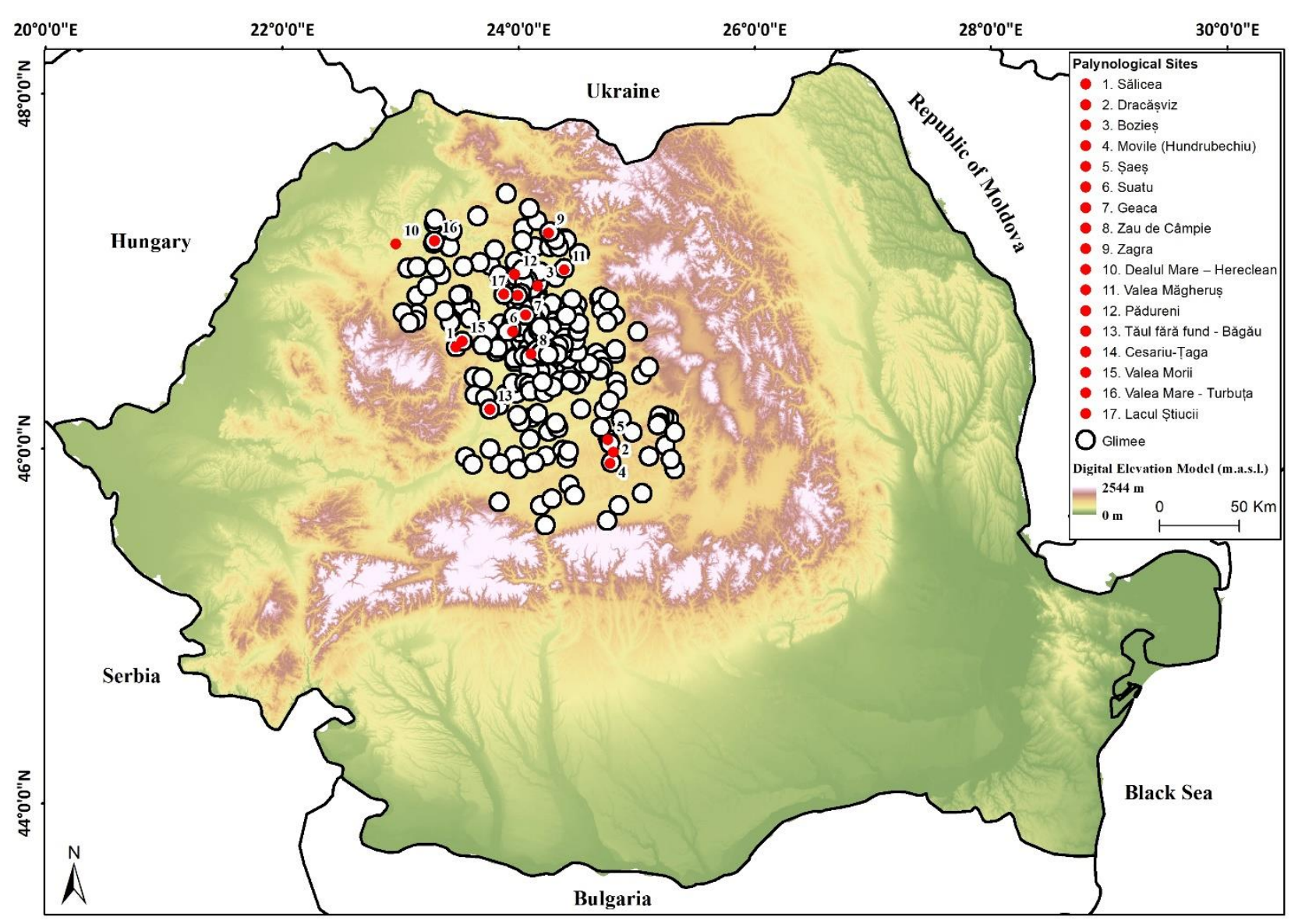

Fig. 1: The geographical location of the analyzed palynological sites and the distribution of the most important glimee in the Transylvanian Depression.

In 1964, Sandulache et al. discusses the origin of lakes in the Transylvanian Plain, taking into account the statements of Morariu [23] who considers both lakes and landslides as Periglacial and respectively Pop [28] who concludes that both morphogenetic phenomena - landslides and lakes in valleys - occurred in the last Postglacial period, in the Subatlantic or even earlier. To clarify this issue, the authors performed palynological analyses in the lakes of Suatu, Geaca and Zau de Cimpie. Based on the pollen spectra obtained, they conclude that the freshwater lakes in the Transylvanian Plain are old, having formed in the Boreal-Atlantic, 7000-8000 yr BP, while the 
dams that reflect anthropogenic activity are much more recent. These results, we believe, are consistent with the hypothesis of the existence of several "phases" of landslides [24].

Another "lake" that aroused interest both from a floristic [27] but also palynological [17] perspective is the Zagra Lake from the landslide area south of the T,ibleș Mountains. Also called Tăul lui Alac, this landslide-dammed lake is located on Dealul Comorii, near the village of Zagra, Bistrița-Năsăud county. According to the author, the swampy lake was a clogged stage of a dam lake, formed in the depression that resulted between the slope and the slidden soil mass. At that time the "lake" itself was represented by two deep bodies of water, surrounded by a swamp. Possibly, it is the area known today as the Zagra Lake Reserve, with an aquatic ecosystem surface of c. 1.8 ha.

Following the palynological analyses, Lupșa reconstructed the history of the vegetation in the region starting with the end of the pine phase, at the passage between Late Glacial and Postglacial. The abundance of rainfall from the Subatlantic led to the formation of a deep water table, as well as the establishment of a Sphagnum peat bog. According to Morariu [22], "the geological disturbance that determined the landslides, the sinking and the appearance of the lake, according to analysis of the pollen and sediments, may have taken place before or during the Quaternary Glaciation, when man had not yet entered this valley."

In the area of glimee from Dealul Mare - Hereclean, near Zalău, Şuteu et al. [34] investigated the vegetation history in the marshy pools formed at an altitude of c. $210 \mathrm{~m}$. The authors state that the foundation of these swamps is represented by an alternation of sandy marls with sands, which were, in a colder and wetter climatic period (Subatlantic) prone to massive landslides. Palynological spectra confirm this hypothesis, reflecting the composition of Subatlantic forests in the region: mixed oaks (Quercetum mixtum $=28-45 \%$ ), composed of sessile and pedunculate oaks, limes, maples, ashes, but also beech (Fagus $=20-30 \%)$, and at higher altitudes spruce (Picea) and even fir (Abies). The overrepresentation of alder (Alnus) in the pollen spectra also suggests a humid edaphon, favored by the humid and colder climate.

Also, Diaconeasa and Mitroescu [7] obtained interesting results by analyzing the pollen of a sequence extracted from the „Tăul fără fund” swamp in Băgău, a clogging lake, formed behind an older landslide. The basal part of the sag pond formed by the landslide is covered with clay material of variable thickness $(7.4-10 \mathrm{~m})$, which turned out to contain both Tertiary and Quaternary pollen. Peat was deposited over the basal clay, its age estimated by the authors on the basis of pollen spectra, in the absence of $\mathrm{C} 14$ dating, as Boreal-Atlantic. The authors also note, over the entire range of analyses, the predominance of forest over grassland ecosystems.

Near Cluj-Napoca, at Valea Morii, Tanțău and Fărcaș [36] analysed two palynological sequences, following the evolution of vegetation in the region starting with the end of the Late Glacial. They revealed the continuous and dominant presence of hill-belt forests throughout the whole Holocene period. Sedimentation was slow in the first part of the Holocene, registering two hiatuses, the first during the Preboreal and the second during the Boreal. The sedimentation rate strongly increased during the Subatlantic, where, however, sterile horizons were also recorded, reflecting the change in sedimentation conditions.

At the north-western limit of the Transylvanian Depression, on Valea Mare, at Turbuţa, the pollen, micro-charcoal and total carbon analyses performed by Feurdean et al. [11] reveal the environmental changes from the Younger Dryas to the Middle Holocene. The results indicate the presence of open pine (Pinus) and birch (Betula) forests with patches of spruce, elm, alder and 
willow (Picea, Ulmus, Alnus and Salix) before 12,000 cal. yr BP. A rather sudden replacement of the dominant species by Ulmus at approx. 11,900 cal. yr BP reflects the effect of competition caused by global warming in the early Holocene. Up to 11,000 cal. yr BP, forests were increasingly diverse and dense, with the expansion of Quercus, Fraxinus and Tilia (oak, ash and lime), the emergence of Corylus (hazel) and the decline of herbaceous taxa.

The marked expansion of Quercus accompanied by Tilia between 10,500 and 8000 cal. yr BP could indicate low humidity, associated with both the low altitude of the site and a regional shift to a drier climate. At 10,000 cal. yr BP, Corylus spread throughout the region, and at 8000 cal. yr BP it replaced Quercus as the dominant forest component. The hornbeam (Carpinus) settled in the area at around 5500 cal. yr BP. The results of this study indicate that during that period the forests in the lowlands of Turbuța have never been closed.

The sediments of the paleolake from Valea Măgheruş provided new data on the development of the Romanian paleo-environment during the Late-Glacial [16]. The studied sediments accumulated after the damming of a small river valley, following a series of events that happened during the de-glaciation period. A continuous sediment sequence belonging to the former lake has been preserved on the banks of the creek and contains evidence of the environmental changes associated with the Late Glacial Interstadial (Bølling-Allerød) and the Late Glacial Stage (Younger Dryas).

These climatic events are reflected by the vegetation dynamics in the region. The Late Glacial Interstadial was warmer and wetter, as shown by the increased organic matter content of the lake, decreased basin erosion, the development of marsh plant communities, and the expansion of Picea during the Allerød interstadial. The Late Glacial Stadial was colder and drier, as indicated by the low content of organic sediments, an increase in erosion markers and a decrease in spruce and its replacement with birch. The landscape was more open, since the herbaceous species expanded during this period. Based on the interpolation of $\mathrm{C} 14$ datings performed on charcoal and wood fragments, the authors concluded that the lake sequence was deposited between a. 15,280 \pm 475 and $12,490 \pm 450$ cal. yr BP.

These studies partially confirm those carried out previously by Diaconeasa [4], which, based on the pollen spectra obtained, and in the absence of C14 dating, frames the sequence studied from Valea Măgheruș in a cold period of the Late Glacial, the accumulation of sediments ending in the Dryas I c (in the Bølling-Allerød Interstadial). The author highlights a pine phase, with several forest episodes: pine, pine-spruce, pine and pine-birch and the absolute dominance of forest vegetation during that period.

Following studies conducted at Lacul Știucii, while trying to elucidate the origin of the forested steppe in Transylvania, Feurdean et al. $[9,10]$ provided the first indisputable evidence for the existence of coniferous forests in this region since the last MIS 3 glacial cycle. The chronological results indicate that the basin of Lacul Știucii is recording the environmental conditions since about 55,000 cal. yr BP (Full Glacial) with probable erosive events between 38,000 and 13,000 cal. yr BP. However, according to the authors, the accumulation of sediments in the last 12,000 cal. yr BP was continuous. These forests endured during MIS 2 and 1, and even predominated before $3700 \mathrm{cal}$. yr BP, challenging the hypothesis that the lowlands of Transylvania were not forested after the last glaciation. However, these forests were never completely "closed", reflecting the climatic conditions (warming) and natural fires, but also the anthropogenic impact, all these factors favouring the persistence of grasslands throughout the Holocene. 
Gârbacea et al. [12] state that the glimee played an important role in the evolution of the Transylvanian landscape. The authors studied the landslides from Pădureni, at the Unguraș Hills, in the N-W part of the Transylvanian Depression. In a longitudinal depression between the first rows of these landslides, an oval-shaped peat bog called "Tăul Fără Fund" formed, with a thickness of about $300 \mathrm{~cm}$. They used a sample taken from the lower part of the sequence $(295 \mathrm{~cm}$ deep), from the failure plane, at the boundary between peat and the basal clay. The entire sequence is $310 \mathrm{~cm}$ long. The lowest part $(10 \mathrm{~cm})$ consists of lacustrine clay, over which they found $5 \mathrm{~cm}$ of organic clay (depth of 300-295 cm). Most of the sequence $(295-0 \mathrm{~cm}$ ) is represented by Sphagnum peat.

For a better understanding of the paleoenvironment and vegetation type around the site during the landslides period, a palynological analysis on a sample from the boundary between peat and basal clay was performed. The results show an "open" forest type of vegetation around the site at that time, composed of 59\% trees and $41 \%$ herbaceous plants and ferns (Pterydophyta) and Sphagnum moss (Bryophyta). The forest vegetation was dominated by Fagus sylvatica (52\%) and Carpinus betulus (23\%). Quercus, Alnus, Ulmus and Betula were also present with lower percentages.

By $\mathrm{C} 14$ dating of the basal layer, the age of landslides was established for the first time in Romania (min. $1820 \pm 30 \mathrm{yr}$ BP, 1694-1825 cal. yr BP). The analysis of the pollen from this layer indicates that the landslide from Pădureni (Transylvania Depression) occurred in the Subatlantic. During this period the vegetation of the studied area consisted of open forests dominated by Fagus sylvatica. The results could indicate a possible period of deforestation that promoted the landslides.

In (probably) the same site, from Pădureni-T,op, in the absence of C14 datings, in an older paper, Diaconeasa [5] considers that the landslide process started before the end of the Subboreal swamping, interpreting the high percentages of hornbeam pollen $(40 \%)$ as belonging to the Subboreal, although in later works [6] he remarks the so-called "revertence" process, i.e. the rebound of hornbeam percentages in Subatlantic, thus placing the age of the swamping in Subatlantic. In fact, Buz et al. [1], following palynological analyzes, reconsider the age of the landslide, stating that the landslide process was related to "the appearance of a wet ecotope, triggered, with sufficient probability, by the Subatlantic climate in its initial phase".

At c. $15 \mathrm{~km}$ from Pădureni, in the palynological profile from Cesariu-T,aga, Diaconeasa \& Mitroescu [8] deduce, based on the pollen spectrum (14C datings lacking), an old date for the swamping, late Late Glacial to early Preboreal. The area was characterized at that time by a cold climate, being dominated by pine forests (Pinus 91\%), sporadically accompanied by spruce (Picea $6 \%$ ), birch (Betula 1.5\%) and alder (Alnus 1.5\%). Within this profile, sterile layers, respectively hiatuses or interruptions in the sedimentation process are noticeable, due to changes in the evolution of the paleoenvironment, having multiple possible causes.

In Romania, the forests dominated by Fagus sylvatica are characteristic of the Subatlantic period (about 2600 cal. yr BP up to the present day) and have been identified in sequences from different areas of the Transylvanian Depression [13, 37, 38]. Where large percentages of Carpinus pollen have been identified in the Subatlantic, they correspond to hornbeam revertence from the Subatlantic period, when, at lower altitudes, mixed forests of hornbeam with oak and/or beech were formed $[6,37,38]$. Also, the high percentages of mixed oaks in certain palynological sequences are due to the lower altitude of the respective sites and the greater distance from the beech formations located at higher altitudes. 
Assessing the chronological sequence of landslide activity during the Holocene can help to better frame their distribution in the wider context of climate change and better define the danger of landslides in order to take appropriate mitigation measures, as stated by Niculiță et al. [25]. The authors classified landslides as very old, old and recent, depending on their morphological appearance and correlation with the studied archaeological sites, and created a model of landslide evolution during the Holocene for the Moldavian Plateau. Based on the data collected, they did not exclude the Pleistocene period for some very old landslides (about 12,000 years ago), while the rest of the landslides took place during the Holocene: the old ones after $6550 \mathrm{BP}$ and up to few centuries ago, while the latest occurred in recent centuries.

The analysis of landslide inventories in the Moldavian Plateau showed a decrease in the size of landslides over time. The more recent landslides tend to be reactivations of older landslides, partially remobilizing their deposits and especially causing the retreat of their escarpments, according to Niculiță et al. [25]. The authors note an evolutionary trend, spatial and dimensional, of Holocene landslide activity in response to climate change.

Table 1: Palynological sites studied in Transylvania

\begin{tabular}{|c|c|c|c|c|c|}
\hline No. & Site name & Climate period & $\begin{array}{l}\text { Geographical } \\
\text { Coordinates }\end{array}$ & $\begin{array}{l}\text { Alt. } \\
(\mathrm{m})\end{array}$ & Reference \\
\hline 1 & Sălicea & Atlantic & $46^{\circ} 40^{\prime} \mathrm{N}, 23^{\circ} 31^{\prime} \mathrm{E}$ & 700 & $\begin{array}{l}\text { Pop E. 1932; Pop G. 1961; } \\
\text { Morariu et al. 1964; Lupșa } 1981\end{array}$ \\
\hline 2 & Dracăşviz & Late Glacial/Preboreal & $\sim 46^{\circ} 08^{\prime} \mathrm{N}, 24^{\circ} 47^{\prime} \mathrm{E}$ & 428 & $\begin{array}{l}\text { Morariu et al. 1964; } \\
\text { Tanțău \& Fărcaș } 1997\end{array}$ \\
\hline 3 & Bozieș & Boreal-Atlantic & $\sim 47^{\circ} 01^{\prime} \mathrm{N}, 24^{\circ} 11^{\prime} \mathrm{E}$ & 435 & Morariu et al. 1964 \\
\hline 4 & $\begin{array}{l}\text { Movile } \\
\text { (Hundrubechiu) }\end{array}$ & Boreal-Atlantic & $\sim 46^{\circ} 01^{\prime} \mathrm{N}, 24^{\circ} 47^{\prime} \mathrm{E}$ & \pm 510 & Morariu et al. 1964 \\
\hline 5 & Șaeș & Boreal-Atlantic & $\sim 46^{\circ} 09^{\prime} \mathrm{N}, 24^{\circ} 46^{\prime} \mathrm{E}$ & 415 & Morariu et al. 1964 \\
\hline 6 & Suatu & Boreal-Atlantic & $46^{\circ} 45^{\prime} 35^{\prime \prime} \mathrm{N}, 23^{\circ} 58^{\prime} 47^{\prime \prime} \mathrm{E}$ & \pm 343 & Săndulache et al. 1964 \\
\hline 7 & Geaca & Boreal-Atlantic & $46^{\circ} 51^{\prime} 08^{\prime \prime N}, 24^{\circ} 05^{\prime} 07^{\prime \prime} \mathrm{E}$ & \pm 289 & Săndulache et al. 1964 \\
\hline 8 & Zau de Cîmpie & Boreal-Atlantic & $46^{\circ} 38^{\prime} \mathrm{N}, 24^{\circ} 08^{\prime} \mathrm{E}$ & \pm 295 & Săndulache et al. 1964 \\
\hline 9 & Zagra & Late Glacial/Preboreal 4 & $47^{\circ} 19^{\prime} \mathrm{N}, 24^{\circ} 16^{\prime} \mathrm{E}$ & 420 & $\begin{array}{l}\text { Pop 1960; Lupșa 1972; } \\
\text { Morariu } 1974\end{array}$ \\
\hline 10 & $\begin{array}{l}\text { Dealul Mare - } \\
\text { Hereclean }\end{array}$ & Subatlantic & $47^{\circ} 14^{\prime} 21^{\prime \prime} \mathrm{N}, 23^{\circ} 00^{\prime} 05^{\prime \prime} \mathrm{E}$ & 210 & Șuteu et al. 1978 \\
\hline 11 & Valea Măgheruş & Late Glacial & $47^{\circ} 05^{\prime} 94^{\prime \prime N}, 24^{\circ} 23^{\prime} 61^{\prime \prime E}$ & 345 & $\begin{array}{l}\text { Diaconeasa } 1979 \\
\text { Lascu et al. } 2015\end{array}$ \\
\hline 12 & Pădurenii & Subatlantic & $47^{\circ} 04^{\prime} 52^{\prime \prime} \mathrm{N}, 23^{\circ} 59^{\prime} 21^{\prime \prime} \mathrm{E}$ & 420 & $\begin{array}{l}\text { Diaconeasa 1985; Buz et al. } \\
\text { 1986; Garbacea et al. } 2015\end{array}$ \\
\hline 13 & $\begin{array}{l}\text { Tăul fără fund - } \\
\text { Băgău }\end{array}$ & Boreal-Atlantic & $46^{\circ} 19^{\prime} \mathrm{N}, 23^{\circ} 48^{\prime} \mathrm{E}$ & 430 & Diaconeasa \& Mitroescu 1987 \\
\hline 14 & Cesariu-Ţaga & Late Glacial/Preboreal 4 & $46^{\circ} 57^{\prime} 43^{\prime \prime N}, 24^{\circ} 01^{\prime} 09^{\prime \prime} \mathrm{E}$ & 250 & Diaconeasa \& Mitroescu 1988 \\
\hline 15 & Valea Morii & Late Glacial $\quad 4$ & $46^{\circ} 42^{\prime} \mathrm{N}, 23^{\circ} 34^{\prime} \mathrm{E}$ & 620 & Tanțău \& Fărcaș 2001 \\
\hline 16 & $\begin{array}{l}\text { Valea Mare - } \\
\text { Turbuța }\end{array}$ & Late Glacial & $47^{\circ} 15^{\prime} 44^{\prime \prime} \mathrm{N}, 23^{\circ} 18^{\prime} 71^{\prime \prime} \mathrm{E}$ & 275 & Feurdean et al. 2007 \\
\hline 17 & Lacul Știucii & Full Glacial & $46^{\circ} 58^{\prime} 04^{\prime \prime} \mathrm{N}, 23^{\circ} 54^{\prime} 10^{\prime \prime} \mathrm{E}$ & 239 & Feurdean et al. 2013; 2015 \\
\hline
\end{tabular}

The reactivation of glimee-type landslides triggered by the increased rainfall in the years 1970 and 1975, and the catastrophic effects they had on the morphology and dynamics of the slopes, highlighted the importance of geological and climatic factors, confirming the possibility of glimee development in the current period [21].

Woody vegetation prevents landslides through its buffer role in the water circuit. Cocean et al. [2] emphasize the major role of vegetation, particularly forests, in rainwater retention and in 
fixing soil and slope materials, and that the mechanical balance of slopes is normally ensured by the shaping action of slope erosion and surface processes. In their view, destabilization occurs as a result of dynamic factors with major potential, such as heavy and prolonged rainfall.

Where the displaced material is covered by forests, geomorphological processes are limited. However, where grasslands are the dominant vegetation type, due to massive deforestation and the inclusion of land in the agricultural circuit, soil erosion processes and torrential runoff are increasing.

On the other hand, the specific geomorphological character of the glimee can indicate a high biodiversity conservation value in the physical-geographical context of the Transylvanian Depression [30]. The vegetation types that develop on the slidden soil mass are often different from the original vegetation of the unaffected slope, certain plant communities being known to have an affinity for landslides [19]. The glimee often provide conditions for particular plant communities, which may represent relics developed during past paleo-environmental conditions, such as the steppe vegetation developed during the Pleistocene [3].

\section{Conclusions}

The analysis of the works that considered this subject indicates two large periods of landslide occurrence, the Pleistocene and the Holocene. It can also be concluded that the landslides did not occur only in the early Holocene, but they are manifesting in Transylvania even during the current Subatlantic period. The factors that trigger them are both abiotic and biotic, among the most important being abundant rainfall alternating with periods of drought, and respectively the intense anthropogenic intervention on the landscape in different ways. Further studies could interconnect these insights and correlate them with the current climate change, to direct the evolution of relief and vegetation in the future.

Acknowledgements: This work was supported by the Core Program PN2019-2022 BIODIVERS 3 BIOSERV project, Contract no. 25N/2019.

\section{REFERENCES}

1. Buz, V., Ciangă, N., Diaconeasa, B., Gârbacea, V., Idu, D.P., 1986, Alunecările de teren de la Pădureni (Ţop), Probleme de Geografie Aplicată, Întreprinderea Poligrafică Cluj: 15-22.

2. Cocean, P., Hognogi, G., Nicula, G., 2010, Alunecările de teren de tip glimee din bazinul superior al Văii Ilișua, Geographia Napocensis, IV (2): 5-19.

3. Dengler, J., Becker, T., Ruprecht, E., Szabó, A., Becker, U., Beldean, M., Bita-Nicolae, C., Dolnik, C., Goia, I., Peyrat, J., Sutcliffe, L.M.E., Turtureanu, P.D., Uğurlu, E., 2012, Festuco-Brometea communities of the Transylvanian Plateau (Romania) - a preliminary overview on syntaxonomy, ecology, and biodiversity, Tuexenia 32: 319-359.

4. Diaconeasa, B., 1979, Analiza sporo-polinica a profilului turbos de pe valea Magheraus (jud. Bistrita-Nasaud), Contrib.Bot., 19: 77-83.

5. Diaconeasa, B., 1985, Analiza palinologică a profilului turbos de la Pădureni-Ţop, jud. Cluj, Contrib.Bot., 25: 71-76.

6. Diaconeasa, B., Fărcaș, S., 1998, L’affirmation subatlantique du charme dans les structures silvestres de Roumanie, Contrib.Bot., 34 (II): 245-252.

7. Diaconeasa, B., Mitroescu, S., 1987, Analize de polen în mlaștina "Tăul fără fund”, jud. Alba, Contrib.Bot., 27: 69-74. 
8. Diaconeasa, B., Mitroescu, S., 1988, Analiza palinologică a stratului de turbă de la Cesariu-Ţaga, jud. Cluj, Contrib.Bot., 28: 117-125.

9. Feurdean, A., Liakka, J., Vanniere, B., Marinova, E., Hutchinson, S.M., Mossbruger, V., Hickler, T., 2013, Holocene fire regime drivers in the lowlands of Transylvania (Central-Eastern Europe): a data-model approach, Quaternary Science Reviews, 81: 48-61.

10. Feurdean, A., Marinova, E., Nielsen, A.B., Liakka, J., Veres, D., Hutchinson, S.M., Braun, M., Timar-Gabor, A., Astalos, C., Mosbrugger, V., Hickler, T., 2015, Origin of the forest steppe and exceptional grassland diversity in Transylvania (central-eastern Europe), Journal of Biogeography, 42 (5): 951-963.

11. Feurdean, A., Mosbrugger, V., Onac, B.P., Polyak, V., Veres, D., 2007, Younger Dryas to mid-Holocene environmental history of the lowlands of NW Transylvania, Romania, Quaternary Research, 68 (3): 364-378.

12. Gârbacea, V., Tanţău, I., Pop, O., Benea, M., 2015, First radiocarbon dating of landslides ("glimee") in Romania, Carpathian Journal of Earth Environment and. Sciences, 10 (3): 217-222.

13. Geantă, A., Tanţău, I., Tămaş, T., Johnston, V.E., 2012, Palaeoenvironmental information from the palynology of an 800 year old bat guano deposit from Măgurici Cave, NW Transylvania (Romania), Review of Palaeobotany and Palynology, 174: 57-66.

14. Grecu, F., Comănescu, L., 2010, Special issues related to the landslides of Romania, Analele Universității București, Geografie, Volum aniversar, 2-10. http://annalsreview.geo.unibuc.ro/2010/2010_Grecu\&Comanescu.pdf

15. Jakab, S., 1981, Modelarea versanţilor din Dealurile Târnavelor prin alunecări de teren, Lucrările Conferinței Naţionale de Ştiința Solului Braşov, Publicațiile Societăţii Naţionale Române pentru Ştiinţa Solului, Bucureşti: 19-26.

16. Lascu, I., Wohlfarth, B., Onac, B.P., Björck, S., Kromer, B., 2015, A Late Glacial paleolake record from an up-dammed river valley in northern Transylvania, Romania, Quaternary International, 388: 87-96.

17. Lupşa, V., 1972, Analiza sporo-polinica a mlastinii de la Zagra (jud. Bistrita-Nasaud), Studii si Cercetări de Biologie, Biologie Vegetală, 24 (4): 363-366.

18. Lupşa, V., 1981, Importanţa conservării înmlăştinirii mezotrofe de la Sălicea/jud. Cluj/. Studii și Comunicări de Ocrotirea Naturii, Suceava, 5: 363-366.

19. Maloș, C.V., 2011, Corelaţii între geologia, procesele geomorfologice şi starea unor specii rare de plante din Bazinul Transilvaniei, Teză de doctorat, Universitatea Babeș-Bolyai, Facultatea de Știința și Ingineria Mediului, Cluj-Napoca.

20. Mărgărint, M.C., Grozavu, A. Patriche, C.V., 2013, Assessing the spatial variability of coefficients of landslide predictors in different regions of Romania using logistic regression, Natural Hazards and Earth System Sciences, 13: 3339-3355.

21. Moldovan, M.-L., 2012, Glimeele din Transilvania - Studiu geomorfologic, Teză de doctorat, Universitatea Babeș-Bolyai, Facultatea de Geografie, Cluj-Napoca.

22. Morariu, I., 1974, Vegetaţia de la „Tău” din Zagra, Studii și Comunicări, Arhiva Someşană: 495-500.

23. Morariu, T., 1958, Raionarea fizico-geografică a Cîmpiei Transilvaniei, Studia Universitatis Babeș-Bolyai, Cluj, seria Geologia-Geographia, III (5), S.II, 1, 14 p.

24. Morariu, T., Diaconeasa, B., Gârbacea, V., 1964, Age of land-slidings in the Transylvanian Tableland, Revue. Roumaine de. Géologie, Géophysique, Géographie, Série de Géographie., 8: 149-154.

25. Niculiță, M., Mărgărint, M.C., Santangelo, M., 2016, Archaeological evidence for Holocene landslide activity in the Eastern Carpathian lowland, Quaternary International 415: 175-189.

26. Pop, E., 1932, Contribuții la istoria vegetației cuaternare din Transilvania, Buletinul Grădinii Botanice și Mueului. Botanic Cluj, 12: 29-102.

27. Pop, E., 1960, Mlaştinile de turbă din R.P.R., Editura Academiei R.P.R., Bucureşti: 255-256.

28. Pop, G., 1961, Rolul variaţiilor climatice postglaciare în formarea terasei inferioare de pe valea Someşului Cald, Studia Universitatis Babeș-Bolyai, Cluj, seria Geologia-Geographia, 1: 163-175.

29. Roșian, G., 2009, Evoluția versanților afectați de alunecări masive de tip glimee. Studiu de caz : versantul drept al Văii Secaşului Mic (sectorul Tău - Secăşel), Geographia Napocensis, III (1): 33-40.

30. Roșian, G., Maloș, C., Muntean, L., Bădărău, S.A., Tahâș, A., Măcicăşan, V., 2012, Condiţionări ale utilizării terenurilor datorate alunecărilor masive de tip glimee. Studiu de caz: alunecările de pe Dealul Ţigla Cătinii (Cămăraşu), ECOTERRA Journal of Environmental Research and Protection, 31: 80-85. 
31. Săndulache, A., Diaconeasa, B., Beju, D., 1964, Contribuţii la studiul lacurilor dulci din Câmpia Transilvaniei, Studia Universitatis Babeș-Bolyai, Cluj, seria Geologia-Geographia., 1: 97-105.

32. Surdeanu, V., Moldovan, M., Anghel, T., Buimaga-Iarinca, S.., Pop, O., Rus, I., 2011, Spatial distribution of deep-seated landslides (glimee) in the Transylvanian Basin, Studia Universitatis Babeș-Bolyai, Cluj, seria Geographia, LVI (2): 3-8.

33. Surdeanu, V., Moldovan, M., Manea, Ș., Rus, I., 2013, Glimeele - o altă interpretare, Asociaţia Geomorfologilor din România, al 29-lea Simpozion Național de Geomorfie, Suceava, 30 mai - 1 iunie 2013, p.30.

34. Şuteu, Ş., Teodorescu, E., Diaconeasa, B., 1978, Prezentul şi trecutul vegetaţiei palustre din tăurile de la Hereclean /jud. Sălaj, Contrib.Bot., 18, 265-268.

35. Tanţău, I., Fărcaş, S., 1997, Cercetări palinologice preliminare efectuate în mlaştina de la Dracăşviz (Podişul Hârtibaciului) - jud. Mureş, Marisia, Tg.Mureş, XXV: 59-68.

36. Tanţău, I., Fărcaş, S., 2001, Recherches pollenanalytiques sur l'histoire de la végétation collinaire de la zone de Cluj, Acta Paleontologica Romaniae, Iaşi, 3: 419-426.

37. Tanțău, I., Fărcaş, S., Beldean, C., Geantă, A., Ştefănescu, L., 2011, Late Holocene paleoenvironments and human impact in Făgăraş Depression (Southern Transylvania, Romania), Carpathian Journal of Earth Environment and. Sciences, 6 (1): $171-178$.

38. Tanţău, I., Reille, M., de Beaulieu, J.-L., Fărcaş, S., 2006, Late Glacial and Holocene vegetation history in the southern part of Transylvania (Romania): pollen analysis of two sequences from Avrig, Journal of Quaternary Sciences, 21 (1): 49-61.

\section{CONSIDERAȚII ASUPRA VÂRSTEI GLIMEELOR DIN TRANSILVANIA}

\section{(Rezumat)}

Lucrarea constituie o sinteză asupra studiilor palinologice care au abordat problema vechimii alunecărilor de teren din Transilvania. Se prezintă configurația paleo-vegetației din zonele respective, dar și factorii probabili, abiotici sau biotici, care au determinat alunecările de teren. Se evidențiază perioada de timp relativă în care au avut loc aceste alunecări de teren în Transilvania. Analiza efectuată indică două mari perioade de declanșare a acestui fenomen, Pleistocenul și Holocenul. 